\title{
Organization Design for Foreign Subsidiaries of Multinational Enterprises: A Contingency Perspective
}

\author{
William Q. Judge \& Shaomin Li \\ College of Business \& Public Administration, Old Dominion University \\ Norfolk, VA 23529, USA \\ E-mail: wjudge@odu.edu
}

Received: October 27, 2011

Accepted: November 22, 2011

Published: February 1, 2012

doi:10.5539/ijbm.v7n3p47

URL: http://dx.doi.org/10.5539/ijbm.v7n3p47

\begin{abstract}
There has been considerable research suggesting ways to design foreign subsidiaries for multinational enterprises. Unfortunately, much of this research is fragmented and some is even contradictory. This study seeks to comprehensively integrate this research stream by distilling the extant literature around two key contingency factors: (1) governance environment of the host country, and (2) the strategic role of the foreign subsidiary. Specifically, we distilled the multi-national organizational design literature using the institutional economics logic coupled with Galbraith's classic organizational design framework. This approach yielded twelve new theoretical propositions that better integrates previous theory and research around the four dimensions of organizational design. The end result is a clearer and more comprehensive understanding of what we know about organizational design in foreign subsidiaries, the novel consideration of governance environment surrounding the subsidiary as an important contingency factor, and guidance for future research in this important area.
\end{abstract}

Keywords: Organizational design, Foreign subsidiaries, Governance environment, Strategic role, Institutional economics perspective

\section{Introduction}

Organizing a company to do business on a global scale remains one of the most complex managerial responsibilities (Galbraith, 2000). Previous research has shown that traditional organizational design principles which were developed for domestically-focused organizations are simply too formal and overly rigid for dealing with the needs to balance multiple perspectives, develop flexible coordination, and foster global mindsets (Bartlett \& Ghoshal, 1989). Furthermore, foreign subsidiaries must deal with unusual challenges to their legitimacy as well as highly complex coordination and specialization issues (Li, Yang \& Lue, 2007).

Therefore, organizational designs created specifically for foreign subsidiaries based on primarily their host country's task environment no longer work adequately in the interdependent world of the twenty-first century, particularly in emerging (Kostova, 1999) and transitioning economies (Peng, 2003). Specifically, we argue that organizational scholars must look beyond the immediate task environment to consider the role of the institutional environment to make effective decisions regarding organizational design for foreign subsidiaries

In addition to considering the institutional environment of the host country, foreign subsidiaries must also be designed to serve various strategic roles (Gupta \& Govindarajan, 1991). In some cases, foreign subsidiaries are given considerable latitude to adapt the product offerings to local customs, unusual customer needs, and/or unique competitive situations. In other cases, foreign subsidiaries are given much less latitude to deviate from a global standard and play specific centrally-coordinated roles for multinational enterprises. Clearly, the strategic role of the foreign subsidiary must also be considered when contemplating design options.

Unfortunately, most of the previous literature that addresses organizational design issues for foreign subsidiaries usually only focuses on one aspect of organizational design and one contingency factor. This perspective is incomplete and often leads to misleading guidelines. What is needed is a conceptual integration of previous fragmentary research into a coherent whole. This study attempts to fill that void.

In sum, this conceptual integration is motivated by the general question of how organizational design is jointly affected by the institutional environment and the firm's strategic role, a question that remains challenging and 
important. Specifically, we develop a contingency perspective based on "actor-centered" institutional environment considerations (Aguilera \& Jackson, 2003) and the strategic role of the foreign subsidiary to yield a set of comprehensive, yet concise theoretical propositions for guiding organizational design decisions.

\section{Brief Overview of the Organizational Design Literature}

The organizational design literature has largely adopted the contingency perspective (Donaldson, 2006). In other words, design scholars assume that there is no one best way to organize and organizational designs are contingent upon important contextual variables (Galbraith, 1973). Many versions of the theory have some variant of the consonance hypothesis embedded in them whereby the organization design needs to be consistent with the environmental context (Pfeffer, 1982).

One contingency variable that has generated much scholarly attention is the task environment surrounding the organizational unit. The task environment is defined as: "those parts of the external environment which are relevant to goal setting and goal attainment of the firm" (Thompson, 1967: 27). Burns and Stalker (1961) first advanced the notion that the design of the organization should be a mechanistic design for stable task environments; and a more organic form for unstable task environments.

Lawrence and Lorsch (1967) built upon this notion by focusing on the uncertainty in the task environment and the ensuing differentiation and integration that the organization required to function properly. Uncertainty within task environments varied considerably, and these scholars noted how organizational designs varied considerably as a result, within the relatively uncertain plastics industry as compared to the relatively certain container industry.

Next, Williamson (1975) argued that one should consider the nature of transaction costs within the task environment to guide organization design. He argued that when transaction costs are relatively low, the task environments can be characterized as a "market" and the organization should be designed as a field unit, a single business firm, or a holding company. On the other hand, he noted that when transaction costs are relatively high, the task environment experiences a "market failure" and the organization can be organized as a "hierarchy", or multi-divisional bureaucratic form. However, Ouchi (1979) also observed that when transaction costs were high and not easily monitored, some organizations do best with an informal "clan" form.

Another major contingency variable that has generated considerable attention is the organizational context. For example, Chandler (1962) argued that after one has considered the organization's overall strategy and its relative size, one can begin to properly design the organization to ensure that the strategy is implemented effectively. First Chandler, and later Galbraith and Kazanjian (1978), argued that relatively small single-business firms should have a functional form. Then as the firm grows, many adopted vertical integration strategies using functional forms with profit centers. Chandler observed that many firms next evolved into a divisional form when they adopt a related-diversified corporate strategy. And when the firm diversifies into multiple unrelated businesses, he argued that the firm should then adopt a holding company structure.

Bartlett and Ghoshal (1989) continued with this organizational contingency perspective by arguing that the multinational organizations should design their foreign subsidiaries around their organizational roles. For example, they argued that when the role of a foreign subsidiary is primarily to sense and exploit local opportunities, the "multinational" form is best. However, when the role of the foreign subsidiary is primarily to implement parent company strategies, the "global" form is best. Also, when the role is focused on leveraging parent company competencies, the "international" form is optimal. Finally, when the role was both differentiated and integrated into a worldwide perspective, the "transnational" form performed best.

While previous environmental contingency theory research has contributed enormously to our understanding of proper organizational design, several problems arise when it comes to multinational organizations. First, because multinational organizations experience multiple task and institutional environments (Hillman \& Wan, 2005; Rosenweig \& Singh, 1991), it is unclear whether the design of the foreign subsidiary should be guided by the home country or host country institutional context. Second, recent research has shown that influences outside of the host country's task environment, such as its political, regulatory, and cultural context, have a major impact on foreign subsidiary success (Kostova, 1999; Xu \& Shenkar, 2002). Third, some scholars argue that the subsidiary's strategic role needs to be pre-eminent due to the growing homogenization of the global economy (Mustaffa, Rashid \& Sambasivan, 2007).

In sum, it is unclear as to whether organizational or environmental factors (or both) should frame the organizational design decision for foreign subsidiaries. In this manuscript, we argue that what is needed is a simultaneous consideration of both contingency factors as well as a clearer specification of organizational 
context to consider in order to enhance organizational effectiveness. Indeed, Hamilton, Taylor and Kashlak (1996) were some of the first scholars to argue that both internal and external factors must be considered when making organization design decisions for foreign subsidiaries within multinational firms. To the best of our knowledge, no one has yet addressed this complex situation in a comprehensive fashion. In this study, we argue that an integrative perspective that considers both the institutional context and the specific strategic role of the foreign subsidiary should be the primary contingency factors when considering organizational design principles for foreign subsidiaries of multinational firms. Furthermore, we assert that the institutional perspective (North, 1990) provides the "theoretical glue" for integrating these meso-level insights.

\section{Key Contingencies Related to Organizational Design for Foreign Subsidiaries}

Institutional theory has demonstrated its power to predict success for organizational changes (Greenwood \& Hinings, 1996), organizational strategies (Peng, 2003), and the co-evolution of organizations and organizational fields (Hoffman, 1999). In addition, it has proven to be especially relevant to describing and explaining the choice behaviors and outcomes associated with those choices by considering differences in institutional governance systems (Griffiths \& Zammuto, 2005; Westney, 1993). Consequently, the next section considers a relatively concise but powerful typology of institutional governance systems using the institutional and political economy literature, similar to Griffiths and Zammuto (2005). This is followed by a description of the actor-centered strategic roles pursued by foreign affiliates. Ultimately, we develop a series of theoretical propositions which consider both the strategic role and the institutional task environment when making organization design decisions for foreign subsidiaries.

\subsection{Governance Environments}

The governance environment is conceptualized as the "macro social, political, legal and economic institutions that shape and constrain micro governance behavior in social, political, and economic exchanges" (Li \& Filer, 2007: 82-83). Previous research has shown that governance environments range along a continuum from rule-based to relation-based (Li \& Samsell, 2009). The following sections describe and explain these two ends of the theoretical continuum which broadly encompass the regulatory, cognitive, and normative aspects of the institutional environment from a typological perspective.

\subsubsection{Rule-based Governance Environment.}

We define a society as having a rule-based governance environment if it has the following features: the law making process is transparent and just (Rawls, 1971), the law adjudication function is independent, and the law application branch is checked and balanced by the law making and law adjudication branches, the state can enforce laws impartially and efficiently, and consequently people predominantly rely on public rules to protect their social and economic exchange. This type of governance environment dominates most mature democracies with advanced markets, and is called by various terms, such as public ordering (Platteau, 1994a, 1994b; Peerenboom, 2002). Countries with high-level rule-based governance environments share common key features: they all tend to have relatively transparent laws and public regulations, effective checks and balances of powers, and an independent judiciary and fair and generally effective enforcement of contracts and property rights.

From the perspectives of information requirements and enforcement mechanisms, societies with rule-based governance environments tend to have the following characteristics. First, they tend to have a reliable, efficient information infrastructure to provide accurate micro-level information on business activities $(\mathrm{Li}$, Park \& $\mathrm{Li}$, 2004). Two elements are vital for such an infrastructure. They are the free flow of competing information (freedom of press) and high-quality public business information, such as accounting, auditing, and credit rating information.

Second, these societies tend to have a high-level public trust (trust between strangers). Contrary to common belief, people in rule-based societies do not always resort to formal procedures (such as lawsuits) to settle dispute or enforce contracts, because that would be extremely costly for the parties involved and the society as a whole. A necessary condition for rule-based system to work efficiently is the establishment of generalized morality that internalizes a set of norms that supports such a public ordering among citizens (Platteau, 1994a).

Third, these societies tend to have a well-established legal infrastructure (e.g., a law-making body, the court system, the army of well-trained police). Building such an infrastructure is costly to the society. Since this cost is sunk and fixed, the more people use it, the lower the legal cost per transaction. Thus, the rule-based system is more efficient in economies with large scale and scope.

\subsubsection{Relation-based Governance Environment}

Opposite of the rule-based governance environment is the total or partial absence of its key features, or private ordering, in which economic exchanges are systematically conducted through and protected by the use of private 
means. A prevalent mode of private ordering is relation-based governance environment characterized by the reliance on informal network and private relations to govern socioeconomic exchanges (Li \& Filer, 2007).

It should be pointed out that in societies with a relation-based system, there also exist public laws. What distinguish them from rule-based societies is that people and firms in relation-based societies tend to circumvent public rules, because the laws are not transparently made; and the state, especially the courts, cannot enforce the public rules impartially, or the enforcement is ineffective and inefficient, compared to those for a rule-based governance environment.

Contrary to the rule-based system, relation-based societies are characterized by a high level of noise in public business information and by government's control over mass media, which blocks the free flow of information. In relation-based societies, accounting and auditing professionals tend to be less independent and their standards tend to be lax. It has been found that countries with a poor legal system and a high level of corruption (a symptom of relation-based governance) tend to have loose accounting standards in terms of disclosure rules (Scofield \& Wilhelm, 2004). As a result, people in relation-based societies rely much less on publicly verifiable information. Private agreements between two transaction parties are based on their mutual relations, which tend to be secretive and not verifiable by a third party.

In addition to--and closely related to--the weakness of the public information infrastructure (lack of press freedom and low accounting standards), relation-based societies tend to have a lower level of generalized public trust. The social norms in relation-based societies emphasize personal loyalty (between close friends or family members) as opposed to public trust (between strangers) (Uslaner, 1999; Pearce, 2001). Gambetta (1988), using an example of the Mafia in Sicily, illustrates how the powerful (local elites, government officials) in relation-based societies deliberately destroy public trust and force people who depend on them to pledge personal loyalty.

From the perspective of monitoring and enforcement, it is not difficult to see that when the extent of the market is small, or the number of transaction partners is small, the average (transaction) cost in relation-based governance can be smaller than that in rule-based governance due to the large fixed (transaction) cost in the latter. In other words, relation-based governance tends to be more efficient in the initial stage of development when the scale and scope of economic exchange is limited to a small number of mostly related parties.

\subsubsection{Impact of Governance Environment on Business}

Of course, no society is purely relation-based or rule-based since every country features elements of both types of governance. Consequently, we may consider the governance environment as a continuum between two poles (Li \& Samsell, 2009), pure relation-based on one end and pure rule-based on the other. However, this relatively concise but theoretically-robust typology enables us to conceptualize and even measure the governance environment to guide important organizational design decisions. Scholars have begun to examine how the governance environment affects patterns of business activities across countries. Li and Filer (2007) show that investors tend to choose direct investment rather than portfolio investment in relation-based societies, because it is easier to protect direct investment using private means. Dixit (2003) examines how people enforce contract in trade under different governance environments (rule-based vs. relation-based) and finds that trade based on private enforcement (relation-based) "prevails only in a sufficiently small world," and external enforcement (rule-based) "is useful only if the world is sufficiently large." Using the rule- vs. relation-based framework, Li and Samsell (2009) study trade flows between countries and find that in general, it is easier to trade with rule-based countries than with relation-based countries. The framework has also been applied to examine international marketing channels (Li, Kirande \& Zhou, 2009) and hiring decisions across countries (Sue-Chan \& Dasborough, 2006).

\section{Strategic Roles for Foreign Subsidiaries}

Porter (1986) distinguished between global industries, in which a firm's competitive position in one country is affected by competition in other countries, from multi-domestic industries, in which competition in each country is independent of competition in other countries. Examples of global industries include automobiles and electronic equipment. Multi-domestic industries include retailing and healthcare. Of course, these different types of industries translate into different strategic roles for foreign subsidiaries (Gupta \& Govindarajan, 2001). Listed below is one prominent description:

Foreign subsidiaries of MNEs in multi-domestic industries are relatively self-sufficient organizations. They rely primarily on inputs from the local environment, set prices based on local competition, and otherwise compete with different firms - including subsidiaries of other MNEs - in the country. By contrast, foreign subsidiaries in 
global industries exhibit a higher degree of interdependence with other subsidiaries within the MNE. Such subsidiaries may be specialized operations that perform only a single step in global value-added chain, such as assembly or sales (Rosenweig \& Singh, 1991: 349).

Unfortunately, previous theory and research provides little guidance as to how to consider both the governance environment and the strategic role of the foreign subsidiary simultaneously. Consequently, in the following section, we attempt to reconcile these two key contingency factors of organization design.

\section{Towards a Contingency Theory of Organization Design for Foreign Subsidiaries}

In developing our theoretical propositions, we draw on Galbraith's (1973) seminal work, who advanced perhaps one of the most comprehensive, enduring, and yet concise arguments about the fundamental elements of organizational design. He argued that the five key elements of any organizational design are the: (1) task faced by the organizational unit (which is determined by its strategic role), (2) the type of people needed, (3) the reward system required, (4) the structure of the authority and lines of communication that facilitate productive human interaction, and (5) the processes necessary to make efficient and effective decisions (see Figure 1).

\section{Insert Figure 1 here}

Our overall consideration in examining the effect of institutional governance environment and strategic role on organizational design is that the macro institutional environment is exogenous to firm strategy. Douglass North insightfully observed that "[i]n a world in which there are no increasing returns to institutions and markets are competitive, institutions do not matter...But, with increasing returns," (or market potentials are not fully realized yet,) "institutions matter" (North, 1990, p. 95). In this sense, as our earlier discussion indicates, rule-based system can achieve high efficiency in a market with large scale and scope, implying that the increasing returns (from additional adjustment or improvement) have been fully achieved. However, firms operating in a relation-based system face more limitations as markets expand, implying that there are potential gains to be made in institutional adjustment by the players.

From the perspective of foreign subsidiaries, a rule-based environment is relatively easy to learn since the public rules are relatively transparent. In contrast, a relation-based environment is more difficult to learn since, by its nature, relation-based governance is private, situation-specific, and secretive. Thus, we argue that the key design contingency for a subsidiary operating in a rule-based environment is its strategic role; whereas the macro-institutional factors dominate organizational design considerations in relation-based governance environments.

\subsection{Staffing Options for Foreign Subsidiaries}

One of the first considerations in organizational design is the people that are needed to help make the organizational unit succeed. Galbraith called this the "people design" issue, and it refers to the recruiting, selection, transfer, promotion, training, development, and leadership style(s) required.

Arguably, one of the most important and unique "people design" decisions that is required for foreign subsidiaries of MNEs is the extent to which the general manager or managing director should be from the home country of the headquarters location, known as a parent-country national (PCN). The alternative, of course, is to staff the general manager/managing director position with a host-country national ( $\mathrm{HCN})$. In addition, third-country nationals (TCNs) can be used as expatriate managers as well, but these managers have the same theoretical impact as the utilization of PCNs so our focus will be on the first two staffing options.

In a recent cross-national study of managing directors of foreign subsidiaries, Harzing (2001) found that roughly $41 \%$ were expatriates (PCNs or TCNs) and $59 \%$ were HCNs. Due to the heightened complexity of managing foreign subsidiaries, leadership issues are more critical to success in foreign subsidiaries than in domestic firms or subsidiaries (Scullion, 1994).

When MNEs first started going abroad, they utilized a standard policy for all foreign staffing decisions. However, that standard policy is no longer the norm as MNEs pursue a wide variety of strategies in a wide variety of host country environments. Edstrom and Galbraith (1977) were among the first to theoretically explain why the international transfer of managers occurs. Specifically, they identified three reasons for using expatriate PCNs. The first and most common reason was to fill positions when competent HCNs were not available in the host country. The second reason for using PCNs was for management development purposes. The idea here is to experientially develop a PCN's ability to assume a senior position within the parent organization at a later date. And the third reason for using PCNs was for organizational development needs (such as transmitting the dominant organizational culture) so as to enhance the control and coordination of foreign subsidiary actions. 
However, there are considerable costs and risks to using PCNs. For example, it is very expensive to send PCNs as it often involves relocation costs, financial allowances, loss of spousal income, maintenance of property in the home country, repatriation difficulties, etc. In addition, PCNs often have difficulty in adapting to local circumstances and suffering cultural myopia (Banai \& Sama, 2000), causing them to fail. Finally, most employees within a foreign subsidiary are typically from the host country, and these individuals may find it difficult to trust and/or understand a senior manager from different country. In sum, this staffing decision is not straightforward. As a result, HCNs are sometimes a more optimal choice than PCNs.

For a subsidiary operating in a rule-based governance environment, strategic task (as opposed to institutional environment) considerations dominate organizational design choices due to the public ordering of economic exchanges. This suggests that in this particular environment when the subsidiary is pursuing a global strategy, a premium is placed on interdependence with the parent firm. Since this situation requires optimal coordination and control with the parent organization, the managing director should most likely come from the parent country or a third country (Galbraith \& Kazanjian, 1986). Perhaps this is why Harzing (2001) recently found that subsidiaries operating in global industries such as computers, telecommunications, electronic equipment, and paper products were more likely to use expatriates as general managers of foreign subsidiaries.

An illustration of a successful expatriate as a managing director leading a global strategy-focused firm in a rule-base environment is the American expatriate, Joe Hogan, managing director of GE Healthcare - a foreign subsidiary operating within the United Kingdom (Khanna \& Raabe, 2007). Summarizing the above discussions, we develop the following proposition:

\section{Proposition 1a: When foreign subsidiaries pursue a global standardization strategy in a rule-based governance environment, expatriate managing directors will generally be more effective than host country nationals, all else being equal.}

When the foreign subsidiary is operating in a rule-based environment and is pursuing a multi-domestic strategy, the need for coordination and control with the parent company is reduced as compared to one pursuing global strategy. In this situation, economic exchange is publicly ordered and relatively transparent so strategic considerations, once again, predominate.

Because the strategic role of the subsidiary is multi-domestic, coordination and control is less of a key success factor. Rather, local knowledge and adaptation to local market conditions is primary. As a result, this suggests that the benefits of HCNs outweigh their costs. Research supports this argument. Harzing (2001) recently found that foreign subsidiaries operating in multi-domestic industries such as food products, advertising services, and business services tended to employ HCNs as managing directors. Interestingly, even Japanese are more likely to employ host country nationals in this situation despite their proclivity to employ PCNs (Belderbos \& Heijtjes, 2005). Perhaps this is why Unilever subsidiaries operating in the United States (a relatively rule-based governance environment) and are known to pursue multi-domestic strategies have discovered that local managing directors (i.e., American managers) seem to work out best (Jones \& Decker, 2007). This literature and logic suggests the following proposition:

\section{Proposition 1b: When foreign subsidiaries pursue a multi-domestic strategy in a rule-based institutional environment, host county managing directors will be generally more effective than expatriates, all else being equal.}

However, when the subsidiary operates in a relation-based environment, the institutional environment dominates organizational design considerations due to the private ordering of economic exchanges. Consequently, in these environments, we would expect the managing directors within subsidiaries operating in relation-based environments to be highly dependent on their personal relationships within the host country for the success of the subsidiary.

On the other hand, the institutional distance with the home country headquarters is larger in this situation, so trust and close interaction between the country manager and the parent organization are critical. An ideal candidate for managing the foreign subsidiary would be someone from the home country and yet knows the host country environment well and is easily accepted by the host country, such as a parent-country national whose ethnic origin is the host country. A case in point is China. A typical pattern for MNCs setting up subsidiaries in China is to send a host country citizen who is a Chinese descendent. For example, Meiwei Cheng, an American national of Chinese origins, successfully directed several American affiliates in China, including AT\&T, General Electric, and Ford (Ford, 2007). 
Supporting this viewpoint, Harzing (2001) found that PCNs (no distinction about ethnic origin was made in her study) were more likely to be used as managing directors within subsidiaries where cultural distance is large, and the overall level of education in the host country is relatively low - common features of relation-based environments. Furthermore, Gong (2003) found that cultural distance, a component of institutional distance implied by operating in a relation-based environment, was positively associated with the utilization of expatriates in Japanese firms. This suggests our third and final proposition on staffing of foreign subsidiaries:

Proposition 1c: When foreign subsidiaries operate in relation-based environments, managing directors who are parent-country nationals with host country origins will generally be most effective, all else being equal.

\subsection{Structural Design Options for Foreign Subsidiaries}

Structural design refers to the formal lines of authority and communication within an organization (Chandler, 1962). For Galbraith and Kazanjian (1978), this refers to the division of labor, the lines of communication and distribution of power within an organization - all key organizational design considerations.

Previous research has demonstrated that foreign subsidiaries experience an "institutional duality" - namely, pressures to adapt the subsidiary to be consistent with either the local host country practices and/or competitive practices, while simultaneously addressing pressures to conform to parent firm operations (Kostova \& Roth, 2002). For firms pursuing a global strategy in a rule-based environment, this suggests that pressures to conform with parent firm operations is paramount and that decision making should be relatively centralized.

Previous literature on multinational firms argues that the firm's organizational structure evolves as its international activities increase (Morrison \& Roth, 1992). In the twenty-first century, the firm develops into either a global area division structure or a global product division structure, depending on its organizational strategy, as foreseen by Bartlett and Ghoshal (1988). When the determination is made to pursue a global standardization strategy, a global product division structure has been found to be the most common and effective approach (Paik \& Sohn, 2004). This particular organizational structure is associated with relatively low levels of decentralization, relatively high dependence on the parent headquarters, and relatively low levels of local R\&D and adaptation of the marketing mix. By way of illustration, GE Healthcare successfully utilizes a product-based structure for its foreign subsidiary located in the United Kingdom (Khanna \& Raabe, 2007) - a highly rule-based governance environment. Summarizing the above, we advance the following proposition:

Proposition 2a: When foreign subsidiaries pursue a global standardization strategy in a rule-based governance environment, a global product-based structure will generally be most effective, all else being equal.

For firms pursuing a multi-domestic strategy, decision making is relatively decentralized and external isomorphism pressures are fundamental to success. This suggests that when the subsidiary unit operates in a rule-based country, competitive factors are more important that host country norms, because rule-based economies tend to have similar institutional environments (Li \& Filer, 2007). Consequently, this implies that the foreign subsidiary should imitate the organizational structure of competitors that operate in the same industry.

There is some empirical support for this theoretical argument. For example, Miller and Eden (2006) found that there was greater conformity with local competitors' strategies and structures when the competitive pressures were higher within the U.S. banking industry. Furthermore, Hillman and Wan (2005) reported that foreign subsidiaries in Western European economies, which are largely although not exclusively comprised of rule-based governance environments, tended to be isomorphic with the most competitive strategies and structures. Perhaps this is why Tata's foreign subsidiaries in Spain tend to structure themselves around industry "best practices" (Chu \& Herrero, 2005). This suggests the following proposition:

\section{Proposition 2b: When foreign subsidiaries pursue a multi-domestic strategy in rule-based governance environments, an organizational structure that imitates successful structures in the same industry will generally be most effective, all else being equal.}

In those situations where the foreign subsidiary operates in relation-based governance environments, economic transactions are privately conducted and markets are relatively difficult to enter for newcomers, especially for foreign firms. This suggests that organizational decisions need to be structured in a relatively decentralized manner to successfully navigate the idiosyncratic nature of relation-based governance environments. Furthermore, the institutional duality pressures will tilt towards imitation of the local organizational structures in this host country. 
Perhaps this is why Guillen (2002) found that foreign subsidiaries that became isomorphic with local competitors performed better in China (a highly relation-based system). Also, Delios and Henisz (2000) demonstrated that multinational firms tended to limit their equity ownership structures for foreign subsidiaries operating in 18 emerging economies, all of which are relatively relation-based governance environments. Anecdotally, it is interesting to note that Tata's foreign subsidiary in Mexico is structured quite similarly to local competitors (Chu $\&$ Herrero, 2005). More formally, we advance the following structural proposition for foreign affiliates operating in relatively relation-based governance environment:

Proposition 2c: When foreign subsidiaries operate in relation-based governance environments, organizational structures that imitate successful local competitors and will generally be most effective, all else being equal.

\subsection{Reward System Design Options for Foreign Subsidiaries}

A third key element of organizational design is the reward system. This system is concerned with how individual performance is going to be measured and/or observed, and what competencies will be encouraged or punished. For Galbraith and Kazanjian (1978), this refers to compensation systems, promotion systems, job design parameters, special awards and honors, and performance evaluation systems. Since all of these design parameters are beyond the scope of this paper, we will focus on the most basic reward design issue, namely, how performance is assessed and evaluated.

As a general rule, the performance of the top management team (TMT) within a foreign subsidiary is harder to evaluate than the performance of the TMT within a domestic subsidiary. The reasons for this are due to the greater physical distances, time zone differences, and political, economic, and cultural differences that exist for foreign subsidiaries. Consequently, it is not surprising that the reward system literature has been found to be particularly lacking for multinational firms (Roth and O’Donnell, 1996).

William Ouchi (1977) developed a powerful yet concise conceptualization of organizational reward systems. Ouchi argued that when an individuals' output is easily observed, rewards should be based on that individual's outputs, or individual results. He called this type of reward system "output control". However, when an individual's output is not easily observed or measured, rewards should be based on that individual's behaviors, or effort. He called this form of reward system "behavior control". Notably, Ouchi and Macguire (1975) argued that the reward system for organizational subunits, such as a foreign subsidiary, need to be matched to their environment and organizational roles. Within multinational corporations, this shift in the reward system can influence the cognitive and strategic focus of foreign subsidiaries (Prahalad \& Doz, 1981).

Within rule-based environments when the foreign subsidiary is pursuing a global standardization strategy, the business is optimized from a global perspective. As a result, foreign subsidiaries often are given directives from the parent company to perform certain tasks that may be suboptimal in their local markets, but optimal in the global market (Prahalad \& Doz, 1981). In other words, the subsidiary is given a programmable task to perform within the global environment and its financial performance in local market is highly uncertain.

Eisenhardt (1985) argued that the higher the task programmability and the greater the outcome uncertainty, the more appropriate it is to use behavioral reward system. As such, this line of research implies that organizational rewards should focus on the behaviors prescribed by the parent company, not overall optimization of the local business within rule-based environments (Doz \& Prahalad, 1981). Indeed, Govindarajan and Fisher (1990) found that high-resource sharing SBUs within multi-divisional firms in the USA tended to perform better when a behavior-based reward system was utilized. Furthermore, Gencturk and Aulakh (1995) found that behavior-based controls were more prominent in foreign subsidiaries that had a relatively high horizontal interdependence, a proxy for global standardization. Illustrating this practice, Toyota has set up an elaborate behavior-based reward system that optimizes knowledge transfer for its foreign subsidiary within the UK (Winfield \& Kerrin, 1996). This suggests the following proposition:

\section{Proposition 3a: When foreign subsidiaries pursue a global standardization strategy within a rule-based governance environment, a behavior-based reward system will generally be most effective, all else being equal.}

However, a subsidiary pursing a multi-domestic strategy is given considerable freedom to optimize the business within a specific local market that does not benefit from global standardization. This strategic flexibility allows the foreign subunit to optimize its business based on local market conditions (Cray, 1984). When the firm operates within a rule-based environment, measurement reliability and transparency of outcomes is relatively high. By way of empirical support, Govindarajan and Fisher (1990) found that low resource sharing amongst 
SBUs within multi-divisional firms performed best when they utilized an output-based reward system. Perhaps this is why subsidiaries from Unilever tend to utilize output-based reward systems within the United States (Jones \& Decker, 2007). This suggests that an output-based reward system which relies on pay for performance, pre-established targets, and numerical records for indices of effectiveness should be used in this situation. Hence, the following proposition is advanced:

Proposition 3b: when foreign subsidiaries pursue a multi-domestic strategy within rule-based governance environments, an output-based reward system will generally be most effective, all else being equal.

In contrast, relation-based environments are quite different environments in which to measure and/or observe results. Because of the idiosyncratic nature of relation-based environments and the relative secrecy by which economic exchanges take place, it is quite difficult to gauge performance outcomes. Furthermore, because interpersonal relationships take longer to cultivate but are essential for success in this particular institutional environment, it may not be feasible or reasonable to base rewards on outputs. Consequently, we would expect input-based reward systems to be more effective within this context. Input-based rewards involve careful selection, training, and acculturation of key employees to assure cultural control, and then cultural norms within the organization to guide decision making and behavior.

Empirically, Hamilton and Kashlak (1999) found that input-based reward systems work best for foreign subsidiaries operating in nations with unstable financial policies, significant government restrictions, and high cultural distance from the parent organization. Furthermore, Baliga and Jeager (1984) argued that input-based reward systems and cultural control work best for foreign subsidiaries based in highly uncertain, culturally-distinct environments.

For a foreign subsidiary entering a relation-based country, the most important investment is to cultivate close relationship with powerful locals. These relationships are not measurable outcomes per se; they are important input. Their value is long-term and tacit. Thus, it makes sense that Sealed Air has a "promotion from within" system for its subsidiary in China (Abrami, Kirby, McFarlan \& Manty, 2008). In sum, we derive the third and final proposition for the type of reward system required for foreign subsidiaries operating in relation-based environments:

Proposition 3c: When foreign subsidiaries operate in relation-based governance environments, input-based reward systems will generally be most effective, all else being equal.

\subsection{Planning Design Options for Foreign Subsidiaries}

A fourth element within the Galbraith design star focuses on the "processes" utilized. One of the key processes that can vary considerably from foreign subsidiary to foreign subsidiary is the formality of the planning process as it relates to relationship between headquarters and the foreign location. In traditional strategic planning processes, the business unit must consider resource constraints, competitive dynamics, and customer trends. However, in multinational contexts, strategic planning must also consider a multiplicity of complex factors whereby such things as budgets must consider exchange rate fluctuations, national exchange controls must be dealt with, and uneven and fluid tax rules must be incorporated into strategic plans. In essence, multinational strategic planning involves matching central expectations to local realities (Herbert, 1999).

When relatively formal planning processes are required, the foreign subsidiary will utilize bureaucratic control mechanisms such as periodic budgets, routine competitive analyses, financial reports, and strategic goals and results. In this planning context, explicit rules and procedures are the norm and these standard operating procedures are used to guide and monitor the foreign subsidiary (Jaeger, 1982).

When the foreign subsidiary's strategic task is global standardization, there is a great need for coordination and integration between the subsidiary and the parent firm's headquarters. If this subsidiary operates within a rule-based environment, transactions are relatively efficient and strategic concerns predominate. These conditions place a premium on a considerably formal planning process. With this approach, the planning process is top-down in nature, with the strategic targets being determined by the headquarters, as illustrated by Boeing's planning process within its foreign subsidiary in the UK (Chakravarthy \& Perlmutter, 1985). We thus have:

Proposition 4a: When foreign subsidiaries pursue a global standardization strategy in a rule-based environment, the planning systems that are relatively formal, follow a top-down planning process, and are conducted on a regular, periodic basis will generally be most effective, all else being equal. 
For firms pursuing a multi-domestic strategy in a rule-based governance environment, there is less a need for resource sharing and coordination of plans due to the relative autonomy of the foreign subsidiary, at least compared to one pursuing a global strategy. In order to emphasize the reward system which is aimed at specific numerical targets, the goal setting process is top-down to accommodate corporate goals, but the planning process is bottom-up to address local competitive conditions. Indeed, this is the planning process used by Procter \& Gamble subsidiaries located in France, Germany and the United Kingdom (Chakravarthy \& Perlmutter, 1985). More formally, we propose the following:

\section{Proposition 4b: When foreign subsidiaries pursue a multi-domestic strategy in a rule-based environment, the planning systems that are moderately formal, and follow a bottom-up planning process, and conducted on a regular, periodic basis will generally be most effective, all else being equal.}

Once again, when the foreign subsidiary is operating in a relation-based environment, strategic considerations become secondary and the governance environment becomes primary. With respect to planning processes, this suggests that subsidiaries operating in these environments need to negotiate both strategic goals and strategic direction with corporate headquarters. Furthermore, standard, calendar-driven planning cycles need to give way to event-based planning whereby plans are formed around key events in the institutional environment.

For example, Jacque and Lorange (1984) demonstrated that regular planning systems had to give way to event-driven, negotiated agreements when considering the foreign subsidiary operating in the relation-based governance environment of Argentina, especially during its hyperinflationary period. Furthermore, getting a license or inviting the local powerful for a site-visit can be time-consuming and costly in a relation-based market, depending whom the foreign firm knows and what resources it takes to get it done. Perhaps this is why Unilever takes this approach for its subsidiaries operating out of Africa (Jones \& Decker, 2007). This suggests our final proposition:

\section{Proposition 4c: When foreign subsidiaries operate in relation-based environments, the strategic goals and initiatives should be informally negotiated with corporate headquarters on an event-based schedule, all else being equal.}

\section{Concluding Remarks}

Davis and Marquis (2005) recently argued that one of the central issues facing organization theory is the diverse and evolving institutional environments of economic systems. Consequently, they argued that organizational scholars need to contextually explain organizational phenomena and relationships, rather than just generalize findings from Western developed economies to the rest of the world. Furthermore, Dacin, Goodstein, and Scott (2002) argued that we need more macro and transnational studies of organizational phenomena as previous institutional theory and research has been overly concerned with micro-level phenomena within an organizational field or an organization. We attempt to be responsive to this call in this particular study by integrating institutional arguments with the multinational organizational design literature.

Specifically, we attempted to integrate and refine the organizational design considerations for foreign subsidiaries of multinational firms. Unlike previous theory and research which has predominantly focused on a single factor's relationship with a single design issue, we emphasize two important contingency factors simultaneously - governance environment and strategic role of the subsidiary - before offering any organizational design guidelines. One of our central theoretical assumptions is that strategic role considerations should dominate design decisions in rule-based governance environments and macro institutional considerations may be dominant in relation-based governance environments. A graphical summary of our theoretical propositions is located in Figure 2, while a textual summary is located in Table 1.

\section{Insert Figure 2 and Table 1 here}

We believe that we have made a relatively comprehensive yet parsimonious contribution toward the development of a general theory of organizational design for foreign subsidiaries of multinational firms located throughout the world under varying institutional conditions. Indeed, while some parts of our propositions have some evidence in the literature, no previous theory or research has assembled these factors into a coherent whole and framed them all within the two contingency factors which we have identified and developed.

Obviously, the next step is to empirically test these proposed relationships. For guidance as to how to measure the foreign subsidiaries strategic role, we encourage the reader to turn to field interviews, as demonstrated by Johannson and Yip (1994), or survey methods, as illustrated by Roth (1992). For ideas regarding the measurement of governance environment, we encourage the reader to refer to $\mathrm{Li}$ and Filer (2007) where 
governance environment was recently used to explain the lack of foreign indirect (portfolio) investment in such relation-based environments as China and Italy. Table 2 contains a sampling of various governance environments derived from that pioneering study.

\section{Insert Table 2 here}

To our knowledge, this is the first study to comprehensively examine organizational design options for foreign subsidiaries. In addition, we expand contingency considerations to both environmental and strategic concerns, and expand our environmental consideration to consider the institutional governance environment. Previous research has demonstrated that the undeveloped institutional environments commonly found in transition and developing economies (Hoskisson, Eden, Lau \& Wright, 2000) requires a rethinking of strategy and organizational design. In our opinion, the organizational design literature needs to focus more on institutional environments as opposed to cultural considerations or task environments, which are subcomponents of the institutional environment. In so doing, we refine and extend the institutional economics perspective (North, 1990) with an actor-centered approach (Greenwood \& Hinings, 1996; Oliver, 1991; 1997).

Managerially, this study offers actionable insights which executives and/or consultants can use to enhance startups in foreign countries, or help to diagnose and address performance problems within existing foreign subsidiaries. We encourage executives to avoid the relatively simplistic approach of a single design policy for all foreign subsidiaries. Instead, our research suggests that executives should take a contingency perspective that focuses on the governance environment as well as the strategic role of the foreign subsidiary.

MNE executives should not underestimate the difficulty of learning how to operate in relation-based environment, because by its nature, relation-based ways of doing business are secretive and cannot be learned through textbooks or even experience in rule-based environments. Our theory suggests that foreign subsidiaries operate under very different conditions in these environments compared to more traditional rule-based environments.

This conceptual argument offers a comprehensive, yet parsimonious integration of the organizational design literature for foreign subsidiaries of multinational firms. Our perspective builds on previous research, but it clarifies when the institutional environment dominates design considerations and when it does not. Furthermore, we consider multiple design contingencies and advance the relatively recent rule-based versus relation-based governance typology for classifying institutional environments.

This framework can be used to guide future empirical research of foreign subsidiaries, as well as accumulate findings. Furthermore, we will advance our understanding of actor-centered institutional theory, as well as provide managerially-useful information to executives in multinational firms. For too long, management scholars have been examining fragmentary organizational issues that cannot be implemented by managers (Hambrick, 1994; 2005). This conceptual integration seeks to redress this imbalance.

\section{References}

Abrami, R., Kirby, W., McFarlan, F., and Manty, T. (2008). Sealed Air China, Harvard Business School Case \# 9-308-051.

Aguilera, R., and Jackson, G. (2003). The cross-national diversity of corporate governance: Dimensions and determinants. Academy of Management Review, 28: 447-467.

Baliga, B., and Jaeger, A. (1984). Multinational corporations: Control systems and delegation issues. Journal of International Business Studies, 15: 25-40. http://dx.doi.org/10.1057/palgrave.jibs.8490480

Banai, M., and Sama, L.M. (2000). Ethical dilemma in MNCs' international stuffing policies. Journal of Business Ethics, 25: 221-235. http://dx.doi.org/10.1023/A:1006079511331

Bartlett, C., and Ghoshal, S. (1989). Managing across borders. Boston: Harvard Business School Press.

Belderbos, R., and Heijltjes, M. (2005). The determinants of expatriate staffing by Japanese multinationals in Asia: Control, learning and vertical business groups. Journal of International Business Studies, 36: 341-354. http://dx.doi.org/10.1057/palgrave.jibs.8400135

Burns, T., and Stalker, G. (1961). The management of innovation. London: Tavistock.

Chakravarthy, B., and Perlmutter, H. (1985). Strategic planning for a global business. Columbia Journal of World Business, 3-10.

Chandler, A. (1962). Strategy and structure. Cambridge, MA: MIT Press. 
Chu, M., and Herrero, G. (2005). Tata Consultancy Services Iberoamerica. Harvard Business School Case \# 9-705-020.

Cray, D. (1984). Control and coordination in multinational corporations. Journal of International Business Studies, 15: 85-98. http://dx.doi.org/10.1057/palgrave.jibs.8490483

Dacin, M., Goodstein, J., and Scott, W.R. (2002). Institutional theory and institutional change: Introduction to the special research forum. Academy of Management Journal, 45: 45-57. http://dx.doi.org/10.5465/AMJ.2002.6283388

Davis, G., and Marquis, C. (2005). Prospects for organization theory in the early twenty-first century: Institutional fields and mechanisms. Organization Science, 16: 332-343. http://dx.doi.org/10.1287/orsc.1050.0137

Delios, A., and Henisz, W. (2000). Japanese firms' investment strategies in emerging economies. Academy of Management Journal, 43: 305-323. http://dx.doi.org/10.2307/1556397

Dixit, A. (2003). Trade expansion and contract enforcement. Journal of Political Economy, 111: 1293-1317. http://dx.doi.org/10.1086/378528

Donaldson, L. (2006). The contingency theory of organizational design: Challenges and opportunities, In Burton, R.M. (ed.) Organization design: The evolving state-of-the-art. New York: Springer: 18-40.

Doz, Y., and Prahalad, C.K. (1981). Headquarters influence and strategic control in MNCs. Sloan Management Review, 23: 15-29.

Edstrom, A., and Galbraith, J. (1977). Transfer of managers as a coordination and control strategy in multinational organizations. Administrative Science Quarterly, 22: 248-263. http://dx.doi.org/10.2307/2391959

Eisenhardt, K.M. (1985). Control: Organizational and economic approaches. Management Science, 31: 134-149. http://dx.doi.org/10.1287/mnsc.31.2.134

Ford. (2007). [Online] Available: http://media.ford.com/article_display.cfm?article_id=28(19.

Galbraith, J. (1973). Designing complex organizations. Reading, MA: Addison-Wesley.

Galbraith, J. (2000). Designing the global corporation. San Francisco: Jossey-Bass.

Galbraith, J., and Kazanjian, R. (1978). Strategy implementation: Structure, systems and process. St. Paul: West Publishing.

Galbraith, J., and Kazanjian, R. (1986). Organizing to implement strategies of diversity and globalization: The role of matrix designs. Human Resource Management, 25: 37-54. http://dx.doi.org/10.1002/hrm.3930250104

Gambetta, D. (1988). Mafia: The price of distrust, In Trust, ed. D. Gambetta. New York: Basil Blackwell.

Gencturk, E., and Aulakh, P. (1995). The use of process and output controls in foreign markets. Journal of International Business Studies, 26: 755-786. http://dx.doi.org/10.1057/palgrave.jibs.8490819

Gong, Y. (2003). Subsidiary staffing in multinational enterprises: Agency, resources, and performance. Academy of Management Journal, 46: 726-739.

Govindarajan, V., and Fisher, J. (1990). Strategy, control systems, and resource-sharing: Effects on business-unit performance. Academy of Management Journal, 33: 259-285. http://dx.doi.org/10.2307/256325

Greenwood, R., and Hinings, C. (1996). Understanding radical organizational change: Bringing together the old and the new institutionalism. Academy of Management Review, 21: 1022-1054.

Griffiths, A., and Zammuto, R. (2005). Institutional governance systems and variations in national competitive advantage: An integrative framework. Academy of Management Review, 30: 823-842. http://dx.doi.org/10.5465/AMR.2005.18378880

Guillen, M. (2002). Structural inertia, imitation, and foreign expansion: South Korean firms and business groups in China. Academy of Management Journal, 45: 509-525. http://dx.doi.org/10.2307/3069378

Gupta, A., and Govindarajan, V. (1991). Knowledge flows and the structure of control within multinational corporations. Academy of Management Review, 16: 768-793.

Hambrick, D.C. (1994). What if the academy actually mattered? Academy of Management Review, 19: 11-16.

Hambrick, D.C. (2005). Venturing outside the monastery. Academy of Management Journal, 48: 961-962. http://dx.doi.org/10.5465/AMJ.2005.19573097 
Hamilton, R., and Kashlak, R. (1999). National influences on multinational corporate control system selection. Management International Review, 39: 167-180.

Hamilton, R., Taylor, V., and Kashlak, R. (1996). Designing a control system for a multinational subsidiary. Long Range Planning, 29: 857-868. http://dx.doi.org/10.1016/S0024-6301(97)82823-3

Harzing, A. (2001). Who's in charge? An empirical study of executive staffing practices in foreign subsidiaries. Human Resource Management, 40: 139-158. http://dx.doi.org/10.1002/hrm.1004

Herbert, T. (1999). Multinational strategic planning: matching central expectations to local realities. Long Range Planning, 32: 81-88. http://dx.doi.org/10.1016/S0024-6301(98)00128-9

Hillman, A., and Wan, W. (2005). The determinant's of MNE subsidiaries' political strategies: Evidence of institutional duality. Journal of International Business Studies, 36: 322-340. http://dx.doi.org/10.1057/palgrave.jibs.8400137

Hoffman, A. (1999). Institutional evolution and change: Environmentalism and the U.S. chemical industry. Academy of Management Journal, 42: 351-371. http://dx.doi.org/10.2307/257008

Hoskisson, Robert, Eden, Lorraine, Lau, Chung and Wright, Mike. (2000). Strategy in emerging economies. Academy of Management Journal, 43: 249-267. http://dx.doi.org/10.2307/1556394

Jacque, L., and Lorange, P. (1984). The international control conundrum: The case of 'hyperinflationary' subsidiaries. Journal of International Business Studies, 15: 185-203. http://dx.doi.org/10.1057/palgrave.jibs. 8490490

Jaeger, A. (1982). Contrasting control modes in multinational corporation: Theory, practice, and implications. International Studies of Management \& Organization, 12: 59-71.

Jones, G., and Decker, S. (2007). Unilever as a "multi-local multinational" 1945-1979. Harvard Business School Case \# 9-808-025.

Khanna, T., and Raabe, E. (2007). GE Healthcare, 2006. Harvard Business School Case \# 9-706-478.

Kostova, T. (1999). Transnational transfer of strategic organization practices: contextual perspective. Academy of Management Review, 24: 308-324. http://dx.doi.org/10.2307/259084

Kostova, T., and Roth, K. (2002). Adoption of an organizational practice by subsidiaries of multinational corporations: Institutional and relational effects. Academy of Management Journal, 45: 215-235. http://dx.doi.org/10.2307/3069293

Lawrence, P., and Lorsch, J. (1967). Organization and environment. Boston: Harvard Business School Press.

Li, S., and Filer, L. (2007). The effects of the governance environment on the choice of investment mode and the strategic implications. Journal of World Business, 42, 80-98. http://dx.doi.org/10.1016/j.jwb.2006.11.006

Li, S., and Samsell, D. (2009). Why some countries trade more than others: The effect of the governance environment on trade flows. Corporate Governance: An International Review, 17: 47-61. http://dx.doi.org/10.1111/j.1467-8683.2008.00715.x

Li, S., Karande, K., and Zhou, D. (2009). Conducting market exchange in different governance environments: The case of the diamond market in the U.S. and China. Journal of Business Ethics. Forthcoming.

Li, S., Park, S.H., and Li, S. (2004). The great leap forward: The transition from relation-based governance to rule-based governance. Organizational Dynamics, 33(1): 63-78. http://dx.doi.org/10.1016/j.orgdyn.2003.11.005

Miller, S., and Eden, L. (2006). Local density and foreign subsidiary performance. Academy of Management Journal, 49: 341-361. http://dx.doi.org/10.5465/AMJ.2006.20786081

Morrison, A., and Roth, K. (1992). A taxonomy of business-level strategies in global industries. Strategic Management Journal, 13: 399-418. http://dx.doi.org/10.1002/smj.4250130602

Mustaffa, Z., Rashid, A., \& Sambasivan, M. (2007). Strategic roles of foreign multinational subsid-iaries in Malaysia. International Journal of Management \& Decision Making, 8: 268-289. http://dx.doi.org/10.1504/IJMDM.2007.012725

North, D. (1990). Institutions, Institutional Change, and Economic Performance. London: Cambridge University Press.

Oliver, C. (1991). Strategic responses to institutional processes. Academy of Management Review, 16: 145-179. 
Oliver, C. (1997). Sustainable competitive advantage: Combining institutional and resource-based views. $\begin{array}{llll}\text { Strategic } \quad \text { Management } & \text { Journal, } & 18 \text { : } & \text { 697-713. }\end{array}$ http://dx.doi.org/10.1002/(SICI)1097-0266(199710)18:9<697::AID-SMJ909>3.0.CO;2-C

Ouchi, W. (1977). The relationship between organizational structure and organizational control. Administrative Science Quarterly, 22: 95-1(20).

Ouchi, W. (1979). A conceptual framework for the design of organizational control mechanisms. Management Science, 25: 833-850. http://dx.doi.org/10.1287/mnsc.25.9.833

Ouchi, W. G., and Maguire, M. (1975). Organizational control - two functions. Administrative Science Quarterly, 20: 559-578. http://dx.doi.org/10.2307/2392023

Paik, Y., and Sohn, J. (2004). Striking a balance between global integration and local responsiveness: The case of Toshiba corporation, Organizational Studies, 12: 347-359.

Pearce, J. (2001). How we can lean how governments matter to management and organization. Journal of Management Inquiry, 10(2): 103-112. http://dx.doi.org/10.1177/1056492601102002

Peerenboom, R. (2002). Social networks, rule of law and economic growth in China: The elusive pursuit of the right combination of private and public ordering. Global Economic Review, 31: 1-20. http://dx.doi.org/10.1080/12265080208422890

Peng, M. (2003). Institutional transitions and strategic choices. Academy of Management Review, 28: 275-296.

Pfeffer, J. (1982). Organizations and organization theory. Boston: Pitman Publishing.

Platteau, J.P. (1994a). Behind the market stage where real societies exist - Part I: The rule of public and private order institutions. Journal of Development Studies, 30(3): 533-577. http://dx.doi.org/10.1080/00220389408422328

Platteau, J.P. (1994b). Behind the market stage where real societies exist - Part II: The rule of public and private

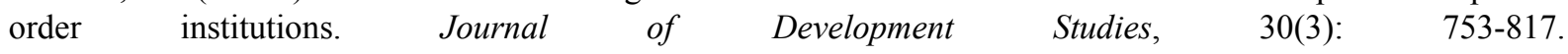
http://dx.doi.org/10.1080/00220389408422338

Porter, M.E. (1986). Changing patterns of international competition. California Management Review, 28(2): $9-40$.

Prahalad, C.K., and Doz, Y. (1981). An approach to strategic control in MNCs. Sloan Management Review, 22: $5-13$.

Rawls, J. (1971). A Theory of Justice. Cambridge: Harvard University Press.

Rosenweig, P., and Singh, J. (1991). Organizational environments and the multinational enterprise. Academy of Management Review, 16: 340-361.

Roth, K. (1992). Implementing international strategy at the business unit level: The role of managerial $\begin{array}{lllll}\text { decision-making characteristics. Journal of Management, } & \text { 18: }\end{array}$ http://dx.doi.org/10.1177/014920639201800410

Roth, K., and O’Donnell, S. (1996). Foreign subsidiary compensation strategy: An agency theory perspective. Academy of Management Journal, 39: 678-703. http://dx.doi.org/10.2307/256659

Scofield, B., and P. Wilhelm. (2004). International accounting standards and corruption. Mimeo. University of Texas, Permian Basin.

Scullion, H. (1994). Staffing policies and strategic control in British multinationals. International Studies of Management \& Organization, 24: 86-104.

Sue-Chan, C., and Dasborough, M. (2006). The influence of relation-based and rule-based regulations on hiring decisions in the Australian and Hong Kong Chinese cultural contexts. International Journal of Human Resource Management, 17(7): 1267-1292. http://dx.doi.org/10.1080/09585190600756640

Thompson, J.D. (1967). Organizations in action. New York: McGraw-Hill.

Uslaner, E. (1999). Democracy and social capital, In Democracy and Trust, ed. M.E. Warren. Cambridge: Cambridge University Press. http://dx.doi.org/10.1017/CBO9780511659959.005

Westney, D. (1993). Institutionalism theory and the multinational corporation, In S. Ghoshal and D. Westney (eds.) Organization theory and the multinational corporation: 53-78. New York: St. Martin's Press.

Williamson, O. (1975). Markets and hierarchies. New York: Free Press. 
Winfield, I., and Kerrin, M. (1996). Toyota Motor Manufacturing in Europe: Lessons for management development. Journal of Management Development, $15(4)$ : 49-56. http://dx.doi.org/10.1108/02621719610116818

Xu, D., and Shenkar, O. (2002). Institutional distance and the multinational enterprise. Academy of Management Review, 27: 608-618.

Table 1. Tabular Summary of Theoretical Propositions Along with Anecdotal Evidence

\begin{tabular}{|c|c|c|c|}
\hline & \multicolumn{3}{|c|}{ Contextual Contingency } \\
\hline & $\begin{array}{c}\text { Global Strategy in } \\
\text { Rule-based Institutional } \\
\text { Environment }\end{array}$ & $\begin{array}{c}\text { Multi-Domestic Strategy in } \\
\text { Rule-based Institutional } \\
\text { Environment }\end{array}$ & $\begin{array}{c}\text { Any strategy in } \\
\text { Relation-based Institutional } \\
\text { Environment }\end{array}$ \\
\hline $\begin{array}{l}\text { People } \\
\text { Design }\end{array}$ & $\begin{array}{l}\text { P1a: Expatriate managing } \\
\text { directors (home country or third } \\
\text { country nationals) are generally } \\
\text { most effective. } \\
\text { Example: American MD of GE } \\
\text { subsidiary located in UK. }\end{array}$ & $\begin{array}{l}\text { P1b: Host country managing } \\
\text { directors are generally most } \\
\text { effective. } \\
\text { Example: American MD of } \\
\text { Unilever subsidiary located in } \\
\text { the USA. }\end{array}$ & $\begin{array}{l}\text { P1c: Parent country nationals } \\
\text { with host country origins are } \\
\text { generally most effective. } \\
\text { Example: American MD with } \\
\text { Chinese origin for Ford } \\
\text { subsidiary located in China. }\end{array}$ \\
\hline $\begin{array}{l}\text { Structural } \\
\text { Design }\end{array}$ & $\begin{array}{l}\text { Example: GE subsidiary located } \\
\text { in UK. }\end{array}$ & $\begin{array}{l}\text { P2b: Mimic competitively } \\
\text { successful industry organizational } \\
\text { structures within a decentralized } \\
\text { decision making structure to be } \\
\text { effective. } \\
\text { Example: Tata subsidiary } \\
\text { located in Spain. }\end{array}$ & $\begin{array}{l}\text { P2c: Mimic locally successful } \\
\text { local organizational structures } \\
\text { within a decentralized decision } \\
\text { making structure to be } \\
\text { effective. } \\
\text { Example: Tata subsidiary } \\
\text { located in Mexico. }\end{array}$ \\
\hline $\begin{array}{l}\text { Reward } \\
\text { Design }\end{array}$ & $\begin{array}{l}\text { P3a: Primarily a behavior-based } \\
\text { reward system to be effective. } \\
\text { Example: Toyota subsidiary } \\
\text { located in UK }\end{array}$ & $\begin{array}{l}\text { P3b: Primarily an output-based } \\
\text { reward system to be effective. } \\
\text { Example: Unilever subsidiary } \\
\text { located in USA }\end{array}$ & $\begin{array}{l}\text { P3c: Primarily an input-based } \\
\text { reward system to be effective. } \\
\text { Example: Sealed Air subsidiary } \\
\text { located in China }\end{array}$ \\
\hline $\begin{array}{l}\text { Planning } \\
\text { Design }\end{array}$ & $\begin{array}{l}\text { P4a: Relatively formal planning } \\
\text { system, top-down planning } \\
\text { process over a regular planning } \\
\text { cycle to be effective }\end{array}$ & $\begin{array}{l}\text { P4b: Relatively formal planning } \\
\text { system, bottom-up planning } \\
\text { process over a regular planning } \\
\text { cycle to be effective. }\end{array}$ & $\begin{array}{l}\text { P4c: Relatively informal } \\
\text { planning system where } \\
\text { strategies are negotiated with } \\
\text { corporate head-quarters within } \\
\text { an event-driven planning cycle } \\
\text { to be effective. } \\
\text { Example: Unilever subsidiary } \\
\text { located in Africa }\end{array}$ \\
\hline
\end{tabular}


Table 2. A Sampling of Governance Environments

\begin{tabular}{|c|c|c|}
\hline Country & Governance Environment Index & \multirow{2}{*}{ Governance Environment } \\
\hline Norway & 6.02 \\
\hline Sweden & 4.69 \\
\hline United States & 4.47 \\
\hline United Kingdom & 4.26 \\
\hline Taiwan & 2.45 \\
\hline South Korea & 1.15 \\
\hline France & 1.09 \\
\hline Italy & 0.56 \\
\hline India & -1.48 \\
\hline Greece & -1.99 \\
\hline Russia & -6.27 \\
\hline China & -7.26 \\
\hline
\end{tabular}

Source: Li \& Filer, 2007.

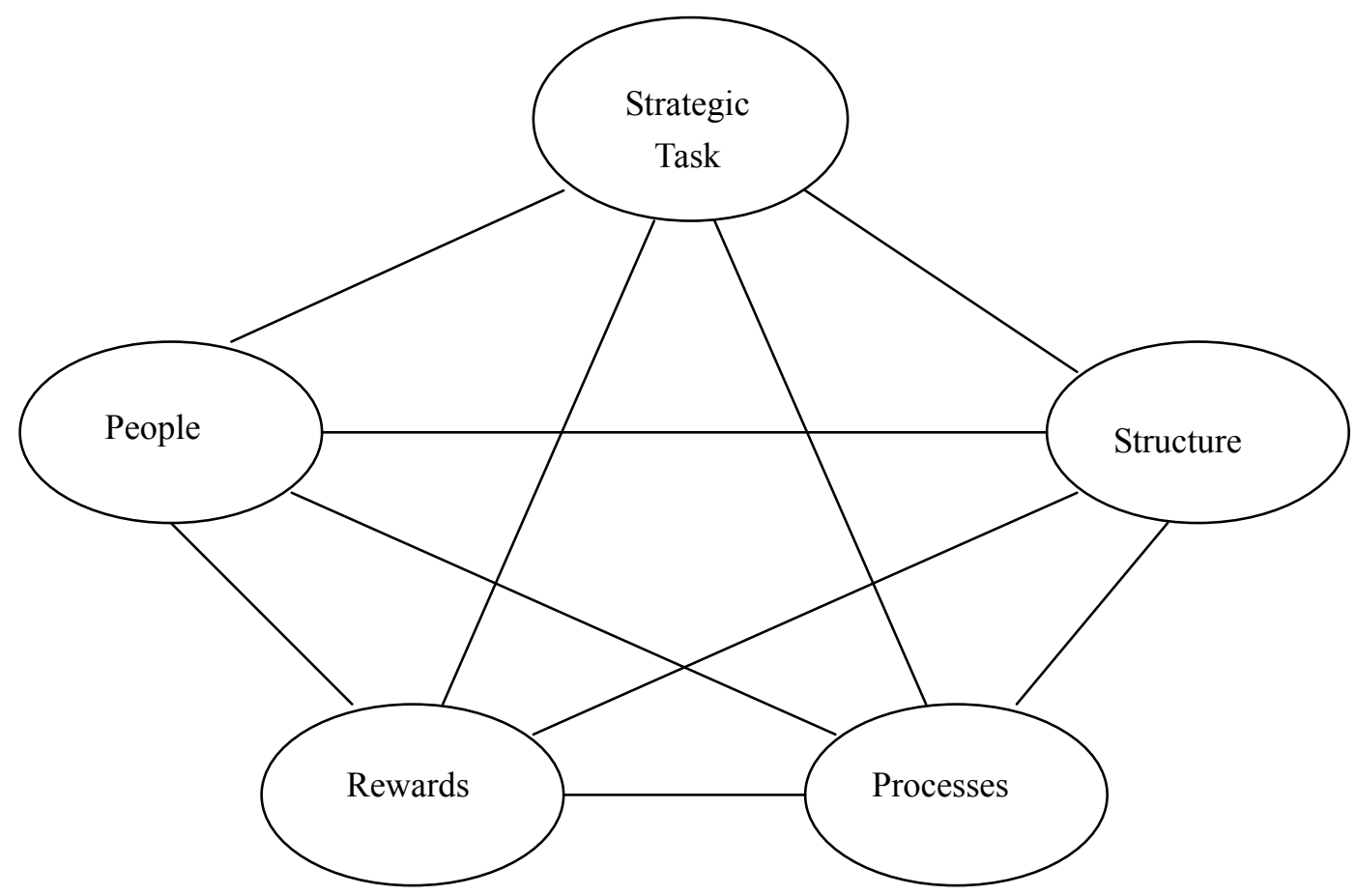

Figure 1. Classic Organizational Design Parameters

Source: Galbraith \& Kazanjian (1986) 


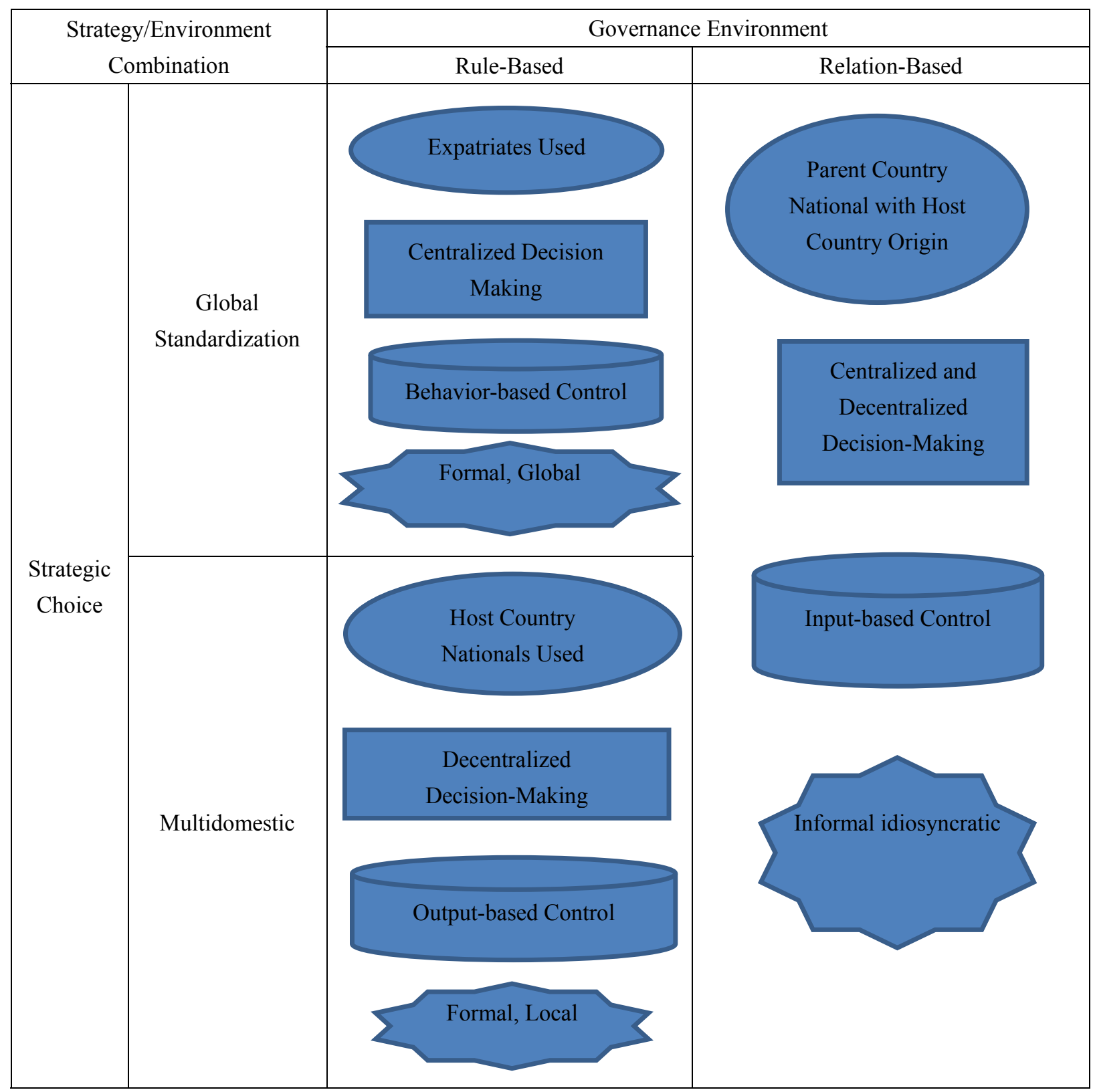

Legend:

Staffing Option/TMT selection

Organizational Structure

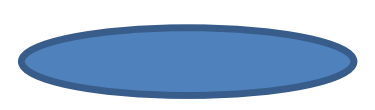

Reward Design

Knowledge Transfer
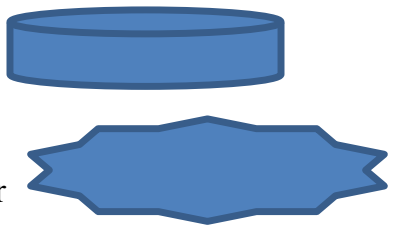

Figure 2. Graphical Summary of Theoretical Propositions 